\title{
The deceptive concept of hypoparathyroidism and recurrence after parathyroidectomy in dialysis patients: are we offering a Procrustean bed to some patients?
}

\section{O enganoso conceito de hipoparatireoidismo e recidiva após paratireoidectomia em pacientes dialíticos: estamos oferecendo uma cama de Procrustes a alguns pacientes?}

Fabio luiz de Menezes Montenegro, TCBC-SP1; Marllia D’Elboux Guimaraes Brescia ${ }^{1}$; Climério Pereira Nascimento Júnior ${ }^{1}$; Ledo Mazzel Massoni Neto ${ }^{1}$; Sérgio Samir Arap ${ }^{1}$; Stênio Roberto Castro lima Santosi'; Patrícia Taschner Goldenstein2; Rodrigo Oliveira Bueno ${ }^{2}$; Melani Ribeiro Custodio²; Vanda Jorgetti2; Rosa Maria Affonso Moyses².

\section{A B S T R A C T}

Objective: to analyze the frequency of hypoparathyroidism and of its recurrence after parathyroidectomy in dialysis patients according to different existing classifications. Methods: we conducted a retrospective study of 107 consecutive dialysis patients undergoing total parathyroidectomy with immediate autograft in a tertiary hospital from 2006 to 2010. We studied the changes in PTH levels in the postoperative period over time. Were grouped patients according to different PTH levels targets recommended according to the dosage method and by the American and Japanese Nephrology Societies, and by an International Experts Consortium. Results: after parathyroidectomy, there was sustained reduction in serum calcium and phosphatemia. The median value of PTH decreased from 1904pg/m/ to 55pg/ml in 12 months. Depending on the considered target level, the proportion of patients below the target ranged between 17\% and $87 \%$. On the other hand, the proportion of patients with levels above the target ranged from 3\% to 37\%. Conclusion: the application of different recommendations for PTH levels after parathyroidectomy in dialysis patients may lead to incorrect classifications of hypoparathyroidism or recurrent hyperparathyroidism and resultin discordant therapeutic conducts.

Keywords: Hyperparathyroidism, Secondary. Parathyroidectomy. Hypoparathyroidism. Dialysis. Parathyroid Hormone

\section{INTRODUCTION}

$\mathrm{D}$ espite recent advances in the clinical treatment of secondary hyperparathyroidism (2HPT) in dialysis patients, parathyroidectomy (PTx) may be necessary in some cases, especially in developing countries, where $10.7 \%$ of dialysis patients present parathyroid hormone (PTH) levels exceeding $1000 \mathrm{pg} / \mathrm{ml}^{1}$. Parathyroidectomy is effective and its cost is lower than the long-term use of cinacalcet ${ }^{2}$. Surgical treatment may improve survival in long-term dialysis population with $2 \mathrm{HPT}^{3,4}$. In the past, PTH levels werenot often monitored after PTX. The objective of the operation was to reverse the $2 \mathrm{HPT}$ symptoms and to achieve normocalcaemia, without the need for supplemental calcium or vitamin D analogues ${ }^{5}$. The availability of PTH dosage exams led to better, still imperfect, understanding of the correlation between
PTH levels and bone and cardiovascular diseases in dialysis patients.

There is consistent evidence of the benefit of PTx regarding survival ${ }^{6}$. Untreated persistent or recurrent $2 \mathrm{HPT}$ can theoretically have a negative effect on quality of life and survival. On the other hand, lower PTH levels were correlated with a worse postoperative survival ${ }^{7}$. Thus, the current target of the operation must be related not only to the demands of calcium and calcitriol, but to the possible actions of PTH on bone, cardiovascular system and, finally, survival.

The problem occurs when oneis to define the appropriate level of PTH to this significantly ill and highly heterogeneous patient population. The document from the National Kidney Foundation, called Kidney Disease Outcomes Quality Initiative (K/DOQI), published in 2003, recommended PTH levels of $150-300 \mathrm{pg} / \mathrm{ml}^{8}$. More recently, the guidelines from Kidney Disease: Improving

1 - Department of Surgery, Faculty of Medicine, University of São Paulo, Sao Paulo, SP, Brazil. 2 - Department of Internal Medicine, Faculty of Medicine, University of Sao Paulo, São Paulo, SP, Brazil. 
Global Outcomes (KDIGO), produced by an international experts consortium, have advocated that PTH levels be maintained twice to nine times the normal upper limit for the appliedassay method ${ }^{9}$. The PTH target levels recommended by the K/DOQI and KDIGO have not been established with the purpose of application to the patient's condition after PTx. However, there is a tendency to extend the recommendation of the PTH levels of these guidelines todialysis patients after the operation.

We set the hypothesis that the use of different criteria for the appropriate levels of PTH after PTx can lead to contradictory recommendations, with unwanted clinical consequences. For example, there may be indication of additional surgical procedures, such as grafting of cryopreserved parathyroid tissue due topresumed hypoparathyroidism or excision of the autograft in the belief of relapsed disease. Even the use of medications, such as prescription calcimimetics or vitamin D analogues, could be suggested according to the adopted PTH target levels.

We analyzed a cohort of patients with severe 2HPT undergoing PTx to assess the impact of the use of different PTH target level proposals on subsequent therapeutic decisions.

\section{METHODS}

We studied dialysis patients operated for 2HPT at a single institution from January 2006 to March 2010. Although their renal replacement therapy were held in different locations in the community, all operations were performed in the same hospital and all patients held regular monitoring in the institution with nephrologists dedicated to bone disease and mineral disorder. Laboratory tests were also carried out in a single clinical pathology laboratory of the institution. The study was approved by ethics in research committee and received registration in the national system of ethics in research under the CAAE 1083.0.015.000-07 number.

We included only patients undergoing one initial operation. We excluded patients with prior successful kidney transplant because their metabolic targets are different from those of individuals on dialysis.
All patients were treated with the intention of total parathyroidectomy with immediate heterotopic parathyroid autograft. Thirty specimens of $2 \times 1 \mathrm{~mm}$ of less sickly appearing parathyroids were macroscopically selected and grafted onto one or more sites, as previously described ${ }^{10}$. The indication for PTx are the ones recommended by the Brazilian Society of Nephrology ${ }^{11}$. We analyzed the following biochemical data before and after the operation: total calcium (tCA, reference values 8.6-10.2 mg/dl), ionized calcium (iCa, 4.6-5.3 mg/dl), phosphorus (P, 2.7-4.5 mg/dl) and PTH (16-87 pg/ml). The PTH intact dosage method used in the institution during the period of study was the IMMULITE 2000 with intra-assay and inter-assay variation of $6.3 \%$ and $5.4 \%$, respectively.

We analyzed the PTH levels of patients at different times postoperatively, ranging from six to 60 months. When the patient received a successful kidney transplant after PTX, he/she was excluded from further analysis, as the full uremic stimulation was interrupted. The PTH values of patients with unresolved persistence were also not included in the postoperative analysis.

We defined three categories: below the recommended target (presumed hypoparathyroidism), within the recommended levels, and above the target level (presumed hyperparathyroidism). We stratified patients in these three categories according to four different recommendations for appropriate levels of PTH: the method's normal values $(16-87 \mathrm{pg} / \mathrm{ml})$; the target proposed by the Japanese Society for Dialysis Therapy $(J S D T)^{12}(60-180 \mathrm{pg} / \mathrm{ml})$; the KDIGO target (2-9 times the method's upper normal limit); and the guidelines of the $\mathrm{K} /$ DOQI (150-300 pg/ml).

Descriptive statistical analysis included the Kolmogorov-Smirnov test for normality. We present continuous data with parametric distribution as mean $( \pm$ standard deviation), and nonparametric distributions as median and interquartile range (Q1-Q3).

We present the scores of patients when stratified according to the aforementioned criteria in absolute and relative values. The statistical inference test employed in each case is described in the results' presentation. 
Table 1. PTH values $(\mathrm{pg} / \mathrm{ml})$ in different periods in months $(\mathrm{m})$.

\begin{tabular}{lccccccc}
\hline & Preoperative & $6 \mathrm{~m}$ & $12 \mathrm{~m}$ & $24 \mathrm{~m}$ & $36 \mathrm{~m}$ & $48 \mathrm{~m}$ & $60 \mathrm{~m}$ \\
\hline $\mathrm{n}^{*}$ & 107 & 97 & 87 & 73 & 61 & 42 & 21 \\
Median & 1904 & 43 & 55 & 47 & 63 & 62,5 & 52 \\
Q1-Q3 & $1,288-2,500$ & $20-112.5$ & $24-105$ & $16-113.5$ & $25-1,975$ & $24-289.8$ & $17.5-169.5$ \\
\hline
\end{tabular}

* $n=$ number of cases with available values for analysis.

\section{RESULTS}

In total, 51 men and 56 women were operated with the intention of total PTx with immediate autografting. The age ranged from nine to 74 years, mean 44.6 $( \pm$ 12.0). The preoperative mean values of tCA, iCa and P were $10.0 \mathrm{mg} / \mathrm{dl}( \pm 0.9), 5.2 \mathrm{mg} / \mathrm{dl}( \pm 0.4)$ and $6.0 \mathrm{mg} / \mathrm{dl}$ $( \pm 1.4)$, respectively. The level of preoperative PTH varied from 425 to $4,539 \mathrm{pg} / \mathrm{ml}$, with a median of $1,904 \mathrm{pg} / \mathrm{ml}$ $(1,288-2,500)$.

In these 107cases, four parathyroid glands were found in 96 individuals. Six patients had persistent 2HPT (5.6\%). In two, the persistence was due to failure to find a fourth parathyroid (1.9\%) and in four, due toa supernumerary parathyroid gland (3.7\%). Three of these six patients lost follow-up before a new operation and the other three underwent a successfulsecond operation, all displaying supernumerary glands at reoperation and their prior parathyroid graft functioned properly after excision of the fifth parathyroid. Thus, the PTx success rate was $94.4 \%$ and, if considered the second operation, the overall rate of success in resolving severe 2 HPT was $97.2 \%$.

Of the study patients, 21 received a successful kidney transplant. The mean time elapsed until transplantation was $28.6( \pm 18.7)$ months after PTx. There was a significant reduction in PTH in all periods after the parathyroid operation, as described in Table 1.

Table 2 brings the postoperative tCA, iCa, and $P$ values. For all three items, only the preoperative values showed a statistically significant difference from all post- operative values ( $p<0.001$, ANOVA and Tukey tests).

The number of patients and their proportions classified as presumed hypoparathyroidism, normal state and presumed hyperparathyroidism according to the different proposed target values are described in Tables 3, 4,5 and 6.

The tables show that, at a given time, the frequency of presumed hypoparathyroidism varies significantly depending on the definition used. At 12 months, it could be as low as $17 \%$ if the normality or the method was considered, or as high as $83 \%$ if the standard KDIGO be the norm. Rather, the presumed hyperparathyroidism wouldvary from $3 \%$ to $37 \%$. The comparison of the differences in the proportions obtained by the use of different definitions for the target PTH, from six to 60 months, was always statistically significant, with $p<0.0001$, confirming the effect of the disagreement between different conceptualizations in establishing the diagnoses of normality, recurrence (hyperparathyroidism) or hypoparathyroidism.

By the same criteria, the comparison of the proportion of patients with hypoparathyroidism, hyperparathyroidism or normal showed no statistically significant change over time, ie, no significant increase in PTH production over the years, in most cases.

\section{DISCUSSION}

In the present study, we showed that there is still no clear definition of hypoparathyroidism and hyperparathyroidism after PTx in dialysis patients. Different

Table 2. Mean ( $\pm S D)$ of $t C a$, iCa and $P$ values $(\mathrm{mg} / \mathrm{dl})$ in different periods in months $(\mathrm{m})$

\begin{tabular}{lccccccc}
\hline & Pre-PTx & $6 \mathrm{~m}$ & $12 \mathrm{~m}$ & $24 \mathrm{~m}$ & $36 \mathrm{~m}$ & $48 \mathrm{~m}$ & $60 \mathrm{~m}$ \\
\hline $\mathrm{tCa}$ & $10.3( \pm 0.9)$ & $8.5( \pm 1.3)$ & $8.4( \pm 1.3)$ & $8.3( \pm 1.5)$ & $8.7( \pm 1.2)$ & $8.8( \pm 1.0)$ & $9.0( \pm 0.8)$ \\
$\mathrm{iCa}$ & $5.2( \pm 0.4)$ & $4.5( \pm 0.8)$ & $4.4( \pm 0.7)$ & $4.7( \pm 1.2)$ & $4.5( \pm 0.7)$ & $4.5( \pm 0.7)$ & $4.6( \pm 0.5)$ \\
$\mathrm{P}$ & $6.0( \pm 1.4)$ & $4.6( \pm 1.7)$ & $4.6( \pm 1.5)$ & $4.8( \pm 1.6)$ & $4.7( \pm 1.4)$ & $4.8( \pm 1.6)$ & $4.5( \pm 1.2)$ \\
\hline
\end{tabular}


Table 3. Number and proportion of patients with hypoparathyroidism and hyperparathyroidism according to the PTH levels recommended by the essay method (16-87pg/ml).

\begin{tabular}{lccc}
\hline & $\begin{array}{c}\text { Hypoparathyroidism }(<16 \mathrm{pg} / \mathrm{ml}) \\
\mathrm{n}(\%)\end{array}$ & $\begin{array}{c}\text { Normal }(16-87 \mathrm{pg} / \mathrm{ml}) \\
\mathrm{n}(\%)\end{array}$ & $\begin{array}{c}\text { Hyperparathyroidism }(>87 \mathrm{pg} / \mathrm{ml}) \\
\mathrm{n}(\%)\end{array}$ \\
\hline 6 months & $21(21.6 \%)$ & $46(47.4 \%)$ & $30(30.9 \%)$ \\
12 months & $15(17.2 \%)$ & $40(46.0 \%)$ & $32(36.8 \%)$ \\
24 months & $17(23.3 \%)$ & $31(42.5 \%)$ & $25(34.2 \%)$ \\
36 months & $10(16.4 \%)$ & $25(41.0 \%)$ & $26(42.6 \%)$ \\
48 months & $8(19.0 \%)$ & $18(42.9 \%)$ & $16(38.1 \%)$ \\
60 months & $4(19.0 \%)$ & $10(47.0 \%)$ & $7(33.4 \%)$ \\
\hline
\end{tabular}

specialized societiesgenerally have different goals for PTH in dialysis patients $8,9,12$. Although these recommendations have not been established for patients after PTx, these target levels are often extrapolated to this new condi$\operatorname{tion}^{13}$. The use of these recommendations determines conflicting diagnoses after PTX.

Studies in dialysis patients suggested survival correlations in "J" or "U" graphical shape between PTH levels and mortality of these patients ${ }^{14}$. In a small retrospective study, survival was also shorter in a subset of patients with a low PTH level after PTX7. However, in a larger retrospective study of a Japanese cohort, the U-shaped associated mortality according to PTH levels was not observed after PTx, and the risk of death was higher only in patients with higher PTH levels after PTX ${ }^{15}$. This evidence suggests a potential clinical interest in defining the appropriate levels of PTH in the long term after PTX.

Stimulation by uremia is often considered as a factor that will determine the progressive increase in PTH levels during the years after PTx. Although this increase occurs in some isolated patients, the proportion of patients in the same category in general has not changed over the years in this series. The attempt to adjust the length of parathyroidectomy deserves further investigation, since the dialysis patient will remain under stimulation and have higher recurrence expectations. The use of PTH dynamic secretion testing would be of great interest in research, but difficult to carry out in routine clinical practice ${ }^{16}$.

The level of PTH after PTx usually guides the decision to graft cryopreserved tissue. In the present study, we show that such indication can vary from $17 \%$ to $83 \%$ of cases, depending solely on the criterion PTH used. Even if we used only the criteria of the nephrology societies, the diagnosis of discordant hypoparathyroidism one year after PTx would be different in $30 \%$ of patients (KDIGO $=83 \%$ and JSDT $=53 \%$ ). Considering this discrepancy, it is reasonable to assume that a part of the patients would receive unnecessary cryopreserved tissue grafts, cryopreservation being a laborious resource that

Table 4. Number and proportion of patients with hypoparathyroidism and hyperparathyroidism according to the PTH levels proposed by JSDT (60$180 \mathrm{pg} / \mathrm{ml}$ ).

\begin{tabular}{lccc}
\hline & $\begin{array}{c}\text { Hypoparathyroidism }(<60 \mathrm{pg} / \mathrm{ml}) \\
\mathrm{n}(\%)\end{array}$ & $\begin{array}{c}\text { Normal }(60-180 \mathrm{pg} / \mathrm{ml}) \\
\mathrm{n}(\%)\end{array}$ & $\begin{array}{c}\text { Hyperparathyroidism }(>180 \mathrm{pg} / \mathrm{ml}) \\
\mathrm{n}(\%)\end{array}$ \\
\hline 6 months & $55(56.7 \%)$ & $23(23.7 \%)$ & $19(19.6 \%)$ \\
12 months & $46(52.9 \%)$ & $27(31.0 \%)$ & $14(16.1 \%)$ \\
24 months & $40(54.8 \%)$ & $24(32.9 \%)$ & $9(12.3 \%)$ \\
36 months & $29(47.5 \%)$ & $16(26.2 \%)$ & $16(26.2 \%)$ \\
48 months & $20(47.6 \%)$ & $9(21.4 \%)$ & $13(30.9 \%)$ \\
60 months & $11(52.4 \%)$ & $6(28.6 \%)$ & $4(19.0 \%)$ \\
\hline
\end{tabular}


Table 5. Number and proportion of patients with hypoparathyroidism and hyperparathyroidism according to the PTH leves proposed by the KIDOQI (150-300 pg/ml).

\begin{tabular}{|c|c|c|c|}
\hline & $\begin{array}{c}\text { Hypoparathyroidism(<150pg/ml) } \\
\text { n (\%) }\end{array}$ & $\begin{array}{c}\text { Normal }(150-300 \mathrm{pg} / \mathrm{ml}) \\
\mathrm{n}(\%)\end{array}$ & $\begin{array}{c}\text { Hyperparathyroidism (>300pg/ml) } \\
\text { n (\%) }\end{array}$ \\
\hline 6 months & $78(80.4 \%)$ & $9(9.3 \%)$ & $10(10.3 \%)$ \\
\hline 12 months & $71(81.6 \%)$ & $8(9.2 \%)$ & $8(9.2 \%)$ \\
\hline 24 months & $60(82.2 \%)$ & $9(12.3 \%)$ & $4(5.5 \%)$ \\
\hline 36 months & $44(72.1 \%)$ & $10(16.4 \%)$ & $7(11.5 \%)$ \\
\hline 48 months & $29(69.0 \%)$ & $4(9.5 \%)$ & $9(21.4 \%)$ \\
\hline 60 months & $15(71.4 \%)$ & $3(14.3 \%)$ & $3(14.3 \%)$ \\
\hline
\end{tabular}

requires expensive maintenance ${ }^{17}$. The cryopreservation of parathyroid is available in few places, often far from the operations' sites ${ }^{18}$. The observations of the current study that PTH levels suffer little change over the years after PTx emphasize the need for a better definition of the appropriate level of PTH in dialysis patients. This pattern would be useful for the decision to use the cryopreserved tissue, avoiding a futile waiting for a delayed function of the autograft, which occurs in a minority of cases. Moreover, it would allow early discarding of the tissues, avoiding unnecessary storage.

The concept of hypoparathyroidism in patients on dialysis after PTx is not easily defined. A better classification is necessary, but the issue is complex. Concern about low reshuffling bone disease associated with low PTH levels guides the various recommendations of the target levels set by experts. The problem is that many of these studies used different PTH detection methods, with many misunderstanding possibilities. In addition, even the third generation assay that would detect only the intact hormone 1-84 molecule may be misleading, as there are oxidized PTH molecules (no biological action in bone remodeling) that affect the measurement, not expressing the actual amount of biologically active hormone ${ }^{19}$.

There is also the concern about the concept of relapse. Although it is clear in patients with PTH levels above $800 \mathrm{pg} / \mathrm{ml}$ and hypercalcemia, our study suggests that recommending the removal of a parathyroid graft based only on the PTH levelis questionable. If the JSDT criterion of excess PTH was used to recommend excision of the autograft, there would be a worsening of the patient's hypoparathyroidism according to the criteria of KDOQI or KDIGO.

The extrapolation of PTH level recommendations to patients after PTx is clearly imperfect. Although an imperfect tool is better than none, its use without critical thinking and care can lead us to act like the Procrustean Bed, in our case resulting in unintentional damage.

Table 6. Number and proportion of patients with hypoparathyroidism and hyperparathyroidism according to the PTH levels proposed by the KDIGO (2 to 9 times the upper normal limit of the essay method).

\begin{tabular}{lccc}
\hline & $\begin{array}{c}\text { Hypoparathyroidism }(<174 \mathrm{pg} / \mathrm{ml}) \\
\mathrm{n}(\%)\end{array}$ & $\begin{array}{c}\text { Normal }(174-783 \mathrm{pg} / \mathrm{ml}) \\
\mathrm{n}(\%)\end{array}$ & $\begin{array}{c}\text { Hyperparathyroidism }(>783 \mathrm{pg} / \mathrm{ml}) \\
\mathrm{n}(\%)\end{array}$ \\
\hline 6 months & $78(80.4 \%)$ & $15(15.5 \%)$ & $4(4.1 \%)$ \\
12 months & $72(82.8 \%)$ & $12(13.8 \%)$ & $3(3.4 \%)$ \\
24 months & $64(87.7 \%)$ & $7(9.6 \%)$ & $2(2.7 \%)$ \\
36 months & $45(73.8 \%)$ & $10(16.4 \%)$ & $7(11.5 \%)$ \\
48 months & $29(69.0 \%)$ & $9(21.4 \%)$ & $4(9.5 \%)$ \\
60 months & $16(76.2 \%)$ & $4(19.0 \%)$ & $1(4.8 \%)$ \\
\hline
\end{tabular}


In Greek mythology, Procrustes was a thief who offered his iron bed for pilgrims to rest on their journey to Eleusis sanctuary. If they were smaller than the bed, Procrustes stretched them until they died. On the contrary, if they were larger than the bed, the villain cut their heads and feet. If necessary, the bed was changed in order to kill any stranger and get hold of his/her belongings. The myth symbolizes the attempt to force the adjustment to an arbitrary measure.

The use of an improper definition of the target PTH level to determine hypoparathyroidism or relapse might erroneously guide surgeons and physicians. The latest JSDT proposal seems to address this need. In this new recommendation, although the upper limit has been raised to $240 \mathrm{pg} / \mathrm{ml}$, the lower one was kept at $60 \mathrm{pg} / \mathrm{ml}$, with the observation that "for patients undergoing PTX, the PTH intact molecule levels are allowed to be below the lower limit of the target range" 20 . This observation of the Japanese school may indicate that other factors are more decisive for cardiovascular risk than a low PTH. Regardless of the PTH level, PTx reduces calcium and phosphorus levels, as shown in these data. This effect on mineral metabolism can have a greater impact on patients' survival than the PTH level alone.

In conclusion, the use of different recommendations for PTH target levels in the dialysis population after PTx can misidentify patients and result in contradictory conducts.

\title{
R E S U M O
}

\begin{abstract}
Objetivo: analisar as frequências de hipoparatireoidismo e de recidiva do hiperparatireoidismo após paratireoidectomia em pacientes dialíticos de acordo com diferentes classificações existentes. Métodos: estudo retrospectivo de 107 pacientes dialíticos consecutivamente submetidos à paratireoidectomia total com autoenxerto imediato em um hospital terciário no período de 2006 a 2010 . A variação dos níveis de PTH no pós-operatório foi estudada ao longo do tempo. Os pacientes foram agrupados de acordo com diferentes metas de níveis de PTH recomendados de acordo com o método de dosagem e pelas sociedades de nefrologia americana, japonesa e de um consórcio internacional de especialistas. Resultados: após a paratireoidectomia, houve redução sustentada da calcemia e fosfatemia. O valor mediano do PTH reduziu-se de 1904pg/ml para 55pg/ml, em 12 meses. Dependendo do nível alvo considerado, a proporção de pacientes abaixo da meta variou entre $17 \%$ e $87 \%$. Ao contrário, a proporção de pacientes com níveis acima da meta variou de $3 \%$ a 37\%. Conclusão: O emprego de diferentes recomendações de níveis de PTH em pacientes dialíticos após paratireoidectomia pode levar a classificações incorretas de hipoparatireoidismo ou hiperparatireoidismo recidivado e implicar em condutas terapêuticas discordantes.
\end{abstract}

Descritores: Hiperparatireoidismo Secundário. Paratireoidectomia. Hipoparatireoidismo. Diálise. Hormônio Paratireoideo.

\section{REFERENCES}

1. Oliveira RB, Silva EN, Charpinel DM, Gueiros JE, Neves $\mathrm{CL}$, Sampaio EA, et al. Secondary hyperparathyroidism status in Brazil: Brazilian census of parathyroidectomy. J Bras Nefrol. 2011;33(4):457-62.

2. Komaba H, Moriwaki K, Goto S, Yamada S, Taniguchi M, Kakuta T, et al. Cost-effectiveness of cinacalcet hydrochloride for hemodialysis patients with severe secondary hyperparathyroidism in Japan. Am J Kidney Dis. 2012; 60(2):262-71.

3. Costa-Hong V, Jorgetti V, Gowdak LH, Moyses RM, Krieger EM, De Lima JJ. Parathyroidectomy reduces cardiovascular events and mortality in renal hyperparathyroidism. Surgery. 2007;142(5):699-703.

4. Goldenstein PT, Elias RM, Pires de Freitas do Carmo L, Coelho FO, Magalhães LP, Antunes GL, et al. Parathyroidectomy improves survival in patients with severe hyperparathyroidism: a comparative study. PLoS One. 2013;8(8):e68870.

5. Rothmund M, Wagner PK, Schark C. Subtotal parathyroidectomy versus total parathyroidectomy and autotransplantation in secondary hyperparathyroidism: a randomized trial. World I Surg. 1991;15(6):745-50.

6. Sharma J, Raggi P, Kutner N, Bailey J, Zhang R, Huang $\mathrm{Y}$, et al. Improved long-term survival of dialysis patients after near-total parathyroidectomy. J Am Coll Surg. 2012;214(4):400-7; discussion 407-8.

7. Fotheringham J, Balasubramanian SP, Harrison B, Wilkie M. Post-parathyroidectomy parathyroid hormone levels: the impact on patient survival - a single-centre study in a stage 5 chronic kidney disease population. Nephron Clin Pract. 2011;119(2):c113-20.

8. National Kidney Foundation. K/DOQI clinical practice guidelines for bone metabolism and disease in chron- 
ic kidney disease. Am J Kidney Dis. 2003; 42(4 Suppl 3):S1-201.

9. Kidney Disease: Improving Global Outcomes (KDIGO) CKD-MBD Work Group. KDIGO clinical practice guideline for the diagnosis, evaluation, prevention, and treatment of Chronic Kidney Disease-Mineral and Bone Disorder (CKD-MBD). Kidney Int Suppl. 2009;(113):S1-130.

10. Caliseo CT, Santos SR, Nascimento CP Jr, Arap SS, Brandão LG, Montenegro FL. Functional results of parathyroid autotransplantation in one single pocket for treatment of secondary hyperparathyroidism. Rev Col Bras Cir. 2011;38(2):85-9.

11. Sampaio EA, Moyses RMA. Paratireoidectomia na DRC. J Bras Nefrol. 2011;33 Suppl 1:S31-4.

12. The guideline committee of the Japanese Society for Dialysis Therapy. [Guidelines for the management of secondary hyperparathyroidism in chronic dialysis patients]. J Jpn Soc Dial Ther. 2006;36:1435-55.

13. Santos $R O$, Ohe $M N$, Carvalho $A B$, Neves $M C$, Kunii I, Lazarerri-Castro M, et al. Total parathyroidectomy with presternal intramuscular autotransplantation in renal patients: a prospective study of 66 patients. J Osteoporos. 2012(2012):631243.

14. Block GA, Klassen PS, Lazarus JM, Ofsthun N, Lowrie EG, Chertow GM. Mineral metabolism, mortality, and morbidity in maintenance hemodialysis. J Am Soc Nephrol. 2004;15(8):2208-18.

15. Komaba H, Taniguchi M, Wada A, Iseki K, Tsubakihara Y, Fukagawa M. Parathyroidectomy and survival among Japanese hemodialysis patients with secondary hyperparathyroidism. Kidney Int. 2015;88(2):350-9.
16. Conti-Freitas LC, Foss-Freitas MC, Lucca $\amalg$, da Costa JA, Mamede RC, Foss MC. Dynamics of parathyroid hormone secretion after total parathyroidectomy and autotransplantation. World J Surg. 2009;33(7):1403-7.

17. Schneider R, Ramaswamy A, Slater EP, Bartsch DK, Schlosser K. Cryopreservation of parathyroid tissue after parathyroid surgery for renal hyperparathyroidism: does it really make sense? World J Surg. 2012; 36(11):2598-604.

18. Barreira CE, Cernea CR, Brandão LG, Custódio MR, Caldini ET, de Menezes Montenegro FL. Effects of time on ultrastructural integrity of parathyroid tissue before cryopreservation. World J Surg. 2011;35(11):2440-4

19. Tepel M, Armbruster FP, Grön HJ, Scholze A, Reichetzeder C, Roth HJ, et al. Nonoxidized, biologically active parathyroid hormone determines mortality in hemodialysis patients. J Clin Endocrinol Metab. 2013; 98(12):4744-51.

20. Fukagawa M, Yokoyama K, Koiwa F, Taniguchi M, Shoji T, Kazama JJ, et al. Clinical practice guideline for the management of chronic kidney disease-mineral and bone disorder. Ther Apher Dial. 2013;17(3):247-88.

Received in: 17/05/2016

Accepted for publication: 18/08/2016

Conflict of interest: none.

Source of funding: none.

\section{Mailing address:}

Fabio Luiz de Menezes Montenegro

E-mail: fabiomonte@uol.com.br fabio.montenegro@hc.fm.usp.br 